\title{
EFEKTIFITAS SERBUK DARI TUMBUHAN SEBAGAI BIOINSEKTISIDA ALAMI DALAM MENGENDALIKAN PERKEMBANGBIAKAN JENTIK NYAMUK AEDES AEGYPTI
}

\author{
Idayani Sangadjisowohy ${ }^{1)}$, Mustafa ${ }^{1)}$ \\ 1) Poltekkes Kemenkes Ternate
}

\begin{abstract}
Abstrak
Latar Belakang. Demam dengue merupakan penyakit akibat nyamuk yang berkembang paling pesat di dunia. Pengendalian nyamuk tidak cukup hanya dengan mengendalikan nyamuknya. Tetapi, jentik nyamuk harus menjadi perhatian juga untuk dikendalikan. Pengendalian jentik nyamuk dapat dilakukan dengan memanfaatkan tumbuhan mulai dari batang, daun, kulit dan akar. Tujuan Penelitian ini adalah untuk mengetahui efektifitas serbuk dari beberapa tumbuhan dalam mematikan jentik Aedes aegypti dengan menggunakan dosis 1 gram/10L dan 2 gram/10L yang dimasukkan kedalam kantung filter teh. Metode Penelitian yang digunakan adalah penelitian experimental sederhana dengan rancangan post test only group control design. Besar sampel yang digunakan adalah 700 ekor jentik Aedes aegypti instar III. Tempat penelitian dilakukan di Laboratorium Vektor dan Binatang Pengganggu Program Studi Sanitasi Poltekkes Kemenkes Ternate. Dosis yang digunakan adalah 1 gram dan 2 gram. Setiap dosis diisi dengan 10 liter air dan diisi 25 ekor jentik, jentik diamati 1 kali 24 jam dengan 3 kali percobaan. Hasil Penelitian ini menunjukkan rata-rata kematian larva selama 24 jam dengan menggunakan serbuk daun sirih pada dosis 1 gram terdapat kematian jnetik yaitu 10 ekor $(13,2 \%)$ dan pada dosis 2 gram yaitu 13 ekor $(17,2 \%)$ kematian jentik. Pada daun cengkeh dengan dosis 1 gram kematian jentik yaitu 13 ekor $(17,2 \%)$, pada dosis 2 gram yaitu 17 ekor $(22,4 \%)$. Sedangkan serbuk daun pala pada dosis 1 gram rata-rata jumlah larva yang mati yaitu 9 ekor $(12 \%)$ dan dosis 2 gram yaitu 10 ekor $(13,2 \%)$ larva yang mati. Kesimpulan dari penelitian adalah semua serbuk daun yang digunakan yaitu sirih,cengkeh dan pala pada semua dosis yang digunakan efektif sebagai larvasida dan serbuk yang paling efektif yaitu serbuk daun cengkeh. Disarankan agar masyarakat dapat memanfaatkan tanaman cengkeh sebagai larvasida untuk mematikan jentik atau mengendalikan jentik.
\end{abstract}

Kata kunci: Jentik Aedes Aegypti, Serbuk Daun Sirih, Serbuk Daun Cengkeh, Serbuk Daun Pala, Efektivitas

\begin{abstract}
Background. Dengue fever is the fastest-growing mosquito-borne disease in the world. Mosquito control is not enough just to control the mosquitoes. Mosquito control is not enough only to control the mosquitoes. However, mosquito larvae must also be a concern to control Mosquito larva control can be done by utilizing plants from stems, leaves, bark, and roots. The purpose of this study was to determine the effectiveness of the powder from several plants in killing Aedes aegypti larvae by using a dose of $1 \mathrm{gram} / 10 \mathrm{~L}$ and 2 grams / 10L which were put into a tea filter bag. The research method used was simple experimental research with a post-test only group control designThe sample size used was 700 instar III Aedes aegypti larvae. The place where the research is conducted is in the Laboratory of Vectors and Nuisance Animals. The dosage used is 1 gram and 2 grams. Each dose was filled with 10 liters of water and filled with 25 larvae, larvae were observed 1 time 24 hours with 3 trials. The results of this study showed the average mortality of larvae for 24 hours using betel leaf powder at a dose of 1 gram, there was 10 larvae mortality (13.2\%) and at a dose of 2 grams, 13 (17.2\%) larvae mortality. In clove leaves with a dose of 1 gram, larvae mortality was 13 (17.2\%), at a dose of 2 grams, 17 (22.4\%). While the nutmeg leaf powder at a dose of $1 \mathrm{gram}$, the average number of dead larvae was 9 (12\%), and a dose of 2 grams was 10 (13.2\%) dead larvae. in conclusion, from this research is that all the leaf powders used are effective as larvicides, while the most effective powder is clove leaf powder. suggested, the community can use the clove plant as a larvicide to kill larvae or control larvae.
\end{abstract}

Keywords: Aedes aegypti larvae, betel leaf powder, clove leaves, nutmeg leaf, effectiveness 


\section{Pendahuluan}

Sebagian besar wilayah tropis dan subtropis sering ditemukan penyakit Demam Berdarah Dengue (DBD), terutama Asia Tenggara, Amerika Tengah, dan Karibia. Manusia adalah host DBD serta virus dengue dengan kategori famili Flaviridae dan genus Flavivirus sebagai agent. Demam dengue merupakan penyakit akibat nyamuk yang berkembang paling pesat di dunia. Berdasarkan jumlah kasus DBD yang dilaporkan secara global oleh World Health Organization (WHO), yakni dari 980 kasus di hampir 100 negara tahun 1954-1959 menjadi 1.016.612 kasus di hampir 60 negara tahun 2000-2009. Kemudian pada tahun 2015 meningkat lagi menjadi 3,4 juta kasus. Tahun 2016 WHO mencatat 15,2 juta kasus DBD di Asia pasifik (WHO, 2017)

Indonesia merupakan salah satu Negara yang endemis DBD. Kejadian demam berdarah jika dilihat dari jumlah kabupaten/kota yang terjangkit demam berdarah dengue menurut Provinsi data DBD pada tahun 2015 - 2017, pada tahun 2015 kabupaten/kota yang terjangkit demam berdarah dengue sebanyak 446 (86,77\%), di tahun 2016 kabupaten/kota yang terjangkit demam berdarah dengue sebanyak 463 (90,08\%), dan pada tahun 2017 kabupaten/kota yang terjangkit demam berdarah dengue sebanyak 434 (84,44\%) (Ditjen P2P, 2018)

Kota Ternate adalah salah satu yang ada di Provinsi Maluku Utara yang edemis DBD. Pada tahun 2014 jumlah DBD dilaporkan sebanyak 51 penderita dan meningal 1 orang pada tahun 2015 menujukan terjadinya penurunan penderita DBD di kota Ternate yaitu terdapat 45 kasus DBD. Kemudian pada tahun 2016 meningkat lagi menjadi 129 kasus. Pada tahun 2017 turun dratis menjadi 20 penderita, kemudian di tahun 2018 naik menjadi 41 kasus penderita dan meningal 3 orang. (Dinas Kesehatan Kota Ternate, 2018)

Masyarakat saat ini masih mengandalkan abate untuk memberantas populasi jentik. Penggunaan abate (temephos) di Indo $\urcorner$ nesia sudah sejak tahun 1976. Empat tahun kemudian yakni tahun 1980, abate (temephos) ditetapkan sebagai bagian dari program pem $\neg$ berantasan massal Aedes aegypti di Indonesia. Bisa dikatakan abate (temephos) sudah digu $\neg$ nakan lebih dari 30 tahun. Selain itu salah satu hal penting yang harus dicermati adalah munculnya resistensi dari berbagai macam spesies nyamuk yang menjadi vektor penyakit. Bukan tidak mungkin, penggunaan abate (temephos) yang bisa dikatakan lebih dari 30 tahun di Indonesia menimbulkan resistensi Laporan resistensi larva Aedes ae-gypti terhadap abate (temephos) sudah ditemu $\neg$ kan di beberapa negara seperti Brazil, Bolivia, Argentina, Kuba, Karibia, dan Thailand. Selain itu juga telah dilaporkan resistensi larva Aedes aegypti terhadap abate (temephos) di Surabaya (Nugroho, 2011)

Melihat dari sudut pandang alasan yang dikemukakan maka perlu adanya suatu usaha untuk mendapatkan insektisida alternatif berbahan alami, yaitu insektisida yang didapati dari tanaman beracun terhadap serangga akan tetapi tidak menimbulkan hal yang negatif terhadap lingkungan dan kesehatan manusia.

Larvisida alami dapat ditemukan pada tumbuhan yang didalamnya mengandung senyawa bahan alam yang berfungsi sebagai larvisida alami. Indonesia memiliki keanekaragaman tumbuhan yang memiliki bahan aktif sebagai insektisida nabati, namun sampai saat ini pe $\neg$ manfaatannya belum dilakukan dengan makาsimal. Begitupun dengan maluku utara memiliki keanekaragaman tumbuhan seperti cengkih, pala, sirih, pandang wangi dan lain-lain. selain sudah terbukti dapat membunuh larva nyamuk, tumbuhan tersebut tentunya aman terhadap manusia atau pun organisme lain, selain itu ba $\neg$ hannya juga mudah didapatkan, dan diharapkan dapat memberi dampak positif pada kesehatan manusia. Bahan aktif yang terkandung dalam tumbuhan ini terdapat pada buah yang men $\neg$ tah, biji, akar, dan daunnya mengandung bahan aktif annonain, saponin, flavonoid, dan tanin. (Utomo et al., 2010)

Penelitian mengenai efektifatas beberapa tumbuhan sebagai larvasida diataranya penelitian (Chintihia, 2015) menunjukan ekstrak daun cengkeh memilik efek larvasida terhadap Aedes aegypti L. dimana pada konsentrasi $150 \mathrm{mg} / \mathrm{L}$ dapat mematikan larva 98,33\% dengan waktu pengamatan selama 24 jam. Hasil penelitian (Puspa et al., 2017) pada daun pala dengan melakukan uji fitokimia untuk melihat toksisitas minyak atsiri daun pala mendapatkan hasil minyak atsiri pada daun pala memiliki toksisitas terhadapa larva aedes aegypti dengan kosentrasi 300 ppm dapat membunuh $80 \%$ larva nyamuk. Penelitian (Sutanto, 2015) dengan menggunakan perasan daun sirih dengan konsentrasi $100 \%$ menyebabkan kematian larva sebesar $50 \%$.

Dari beberapa penelitian yang meneliti mengenai tumbuhan sebagai larvasida alami, sebagian besar masih dilakukan dalam bentuk ekstrak maupun dalam bentuk larutan yang memakai perbandingan tidak seimbang yang menimbulkan air menjadi bau. Berdasar $\neg$ kan uraian di atas, maka permasalahan dalam penelitian ini adalah bagaimana potensi tumbuhan dalam bentuk serbuk atau sebagai bioinsektisida dalam mengendalikan perkembangbiakan jentik nyamuk aedes agypti di kota Ternate.

\section{Alat dan Metode}

Jenis penelitian yang digunakan dalam penelitian ini adalah penelitian eksperimental sederhana dengan rancangan post test only group 
control design. Penelitian ini dilakukan untuk mengetahui efektifitas serbuk daun cengkeh, daun pala dan daun sirih dalam mematikan jentik Aedes aegypti dengan menggunakan dosis 1 gram dan 2 gram dengan air 10 liter setiap wadah. Pengulangan dilakukan sebanyak 3 kali.

Sampel dalam penelitian ini adalah larva Aedes aegypti instar III/IV. Pemilihan instar III/IV sebagai fase uji karena ukurannya lebih besar dibandingkan dengan instar I dan II serta sudah memiliki alat-alat (organ tubuh) yang lengkap dan relative stabil terhadap lingkungan. Selain itu larva instar III dan IV memiliki ketahanan fisik terhadap faktor mekanis saat terjadi pemindahan larva. (Arwadeni, 2015).

Teknik sampling yang digunakan adalah purposive sampling, yaitu metode pemilihan subjek berdasarkan atas ciri-ciri atau sifat tertentu yang berkaitan dengan karakter populasi. Sifat tertentu yang dipakai pada penelitian ini adalah dipakainya sampel larva Aedes aegypti khusus pada fase instar III dan IV.

\section{Hasil dan Pembahasan}

Tabel 1. Uji Efektivitas Serbuk Daun Cengkeh Dalam Kemasan Paper Tea Bag Terhadap Kematian Jentik Aedes aegypti

\begin{tabular}{|c|c|c|c|c|c|c|c|}
\hline \multirow{4}{*}{ Dosis } & \multirow{4}{*}{$\begin{array}{c}\text { Jumlah } \\
\text { Jentik }\end{array}$} & \multirow{2}{*}{\multicolumn{3}{|c|}{$\begin{array}{c}\text { Waktu } \\
\text { Pengamatan } \\
(24 \text { Jam })\end{array}$}} & \multirow{4}{*}{$\mathbf{N}$} & \multirow{4}{*}{$\begin{array}{c}\text { Rata } \\
\text { rata }\end{array}$} & \multirow{4}{*}{$\%$} \\
\hline & & & & & & & \\
\hline & & \multicolumn{3}{|c|}{ Percobaan } & & & \\
\hline & & P1 & $\mathbf{P 2}$ & P3 & & & \\
\hline 1 gram & 25 & 4 & 4 & 5 & 13 & 4,3 & 17,2 \\
\hline 2 gram & 25 & 5 & 5 & 7 & 17 & 5,6 & 22,4 \\
\hline Kontrol & 25 & 0 & 0 & 0 & 0 & 0 & 0 \\
\hline
\end{tabular}

Sumber : Data Primer, 2020

Berdasarkan tabel 1 kematian jentik terbanyak pada dosis 2 gram dengan rata-rata jumlah kematian jentik sebanyak 5,6 (22,4\%), sedangkan pada kontrol tidak terdapat kematian jentik.

Tabel 2. Uji Efektivitas Serbuk Daun Pala Dalam Kemasan Paper Tea Bag Terhadap Kematian Jentik Aedes aegypti

\begin{tabular}{|c|c|c|c|c|c|c|c|}
\hline \multirow{4}{*}{ Dosis } & \multirow{4}{*}{$\begin{array}{c}\text { Jumlah } \\
\text { Jentik }\end{array}$} & \multirow{2}{*}{\multicolumn{3}{|c|}{$\begin{array}{c}\text { Waktu } \\
\text { Pengamatan } \\
(\mathbf{2 4} \text { Jam })\end{array}$}} & \multirow[t]{4}{*}{$\mathbf{N}$} & \multirow{4}{*}{$\begin{array}{c}\text { Rata } \\
- \\
\text { rata }\end{array}$} & \multirow[t]{4}{*}{$\%$} \\
\hline & & & & & & & \\
\hline & & \multicolumn{3}{|c|}{ Percobaan } & & & \\
\hline & & P1 & $\mathbf{P 2}$ & P3 & & & \\
\hline 1 gram & 25 & 3 & 3 & 3 & 9 & 3 & 12 \\
\hline 2 gram & 25 & 4 & 3 & 3 & 10 & 3,3 & 13,2 \\
\hline Kontrol & 25 & 0 & 0 & 0 & 0 & 0 & 0 \\
\hline
\end{tabular}

Sumber : Data Primer, 2020

Berdasarkan tabel 2 hasil jumlah rata - rata kematian jentik nyamuk Aedes aegypti dengan tiga kali percobaan yaitu pada dosis 1 dan 2 gram dengan jumlah rata - rata kematian jentik sama yaitu sebanyak 4 $(16 \%)$. Sedangkan pada kontrol tidak terdapat kematian jentik.

Tabel 3. Uji Efektivitas Serbuk Daun Sirih Dalam Kemasan Paper Tea Bag Terhadap Kematian Jentik Aedes aegypti

\begin{tabular}{|c|c|c|c|c|c|c|c|}
\hline \multirow{4}{*}{ Dosis } & \multirow{4}{*}{$\begin{array}{c}\text { Jumlah } \\
\text { Jentik }\end{array}$} & \multirow{2}{*}{\multicolumn{3}{|c|}{$\begin{array}{c}\begin{array}{c}\text { Waktu } \\
\text { Pengamatan } \\
(24 \text { Jam })\end{array} \\
\text { Daun Sirih }\end{array}$}} & \multirow{4}{*}{$\mathbf{N}$} & \multirow{3}{*}{$\begin{array}{c}\text { Rata } \\
- \\
\text { rata }\end{array}$} & \multirow{4}{*}{$\%$} \\
\hline & & & & & & & \\
\hline & & \multicolumn{3}{|c|}{ Percobaan } & & & \\
\hline & & P1 & P2 & $\mathbf{P 3}$ & & & \\
\hline 1 gram & 25 & 3 & 3 & 4 & 10 & 3,3 & 13,2 \\
\hline 2 gram & 25 & 3 & 5 & 5 & 13 & 4,3 & 17,2 \\
\hline Kontrol & 25 & 0 & 0 & 0 & 0 & 0 & 0 \\
\hline
\end{tabular}

Sumber : Data Primer, 2020

Berdasarkan tabel 3 hasil jumlah rata - rata kematian jentik nyamuk Aedes aegypti dengan tiga kali percobaan yaitu pada dosis 1 gram dengan jumlah rata - rata kematian jentik sebanyak 3,3 (13,2\%). Untuk dosis 2 gram jumlah rata - rata kematian jentik sebanyak 4,3 (17,2\%), sedangkan pada kontrol tidak terdapat kematian jentik

Tabel 4. Perbandingan Rata-rata Kematian Jentik Setelah Pemberian Serbuk Daun Sirih, Daun Cengkeh dan Daun Pala Dengan Tiga Kali Percobaan

\begin{tabular}{|c|c|c|c|c|c|c|}
\hline \multirow{2}{*}{$\begin{array}{c}\text { Dosis } \\
\text { (gram })\end{array}$} & \multicolumn{2}{|c|}{ Daun Sirih } & \multicolumn{2}{c|}{$\begin{array}{c}\text { Daun } \\
\text { Cengkeh }\end{array}$} & \multicolumn{2}{c|}{ Daun Pala } \\
\cline { 2 - 7 } & $\mathbf{N}$ & $\begin{array}{c}\text { Rata- } \\
\text { rata } \\
(\%)\end{array}$ & $\mathbf{N}$ & $\begin{array}{c}\text { Rata- } \\
\text { rata } \\
(\%)\end{array}$ & $\mathbf{N}$ & $\begin{array}{c}\text { Rata- } \\
\text { rata } \\
(\%)\end{array}$ \\
\hline 1 gram & 10 & $\begin{array}{c}3,3 \\
(13,2)\end{array}$ & 13 & $\begin{array}{c}4,3( \\
17,2)\end{array}$ & 9 & $3(12)$ \\
\hline 2 gram & 13 & $\begin{array}{c}4,3 \\
(17,2)\end{array}$ & 17 & $\begin{array}{c}5,6 \\
(22,4)\end{array}$ & 10 & $\begin{array}{c}3,3 \\
(13,2)\end{array}$ \\
\hline Kontrol & 0 & 0 & 0 & 0 & 0 & 0 \\
\hline
\end{tabular}

Sumber : Data Primer, 2020

Berdasarken tabel 4, penelitian yang dilakukan dalam 3 kali percobaan menunjukkan bahwa nilai rata-rata kematian jentik yang paling tinggi terdapat pada daun cengkeh dengan kematian rata - rata jentik pada dosis 1 gram yaitu 17, $2 \%$ kematian jentik dan pada dosis 2 gram rata-rata kematian jentik sebesar $22,4 \%$

Pada penelitian ini terlihat adanya kematian jentik Aedes aegypti pada semua percobaan, ini memperlihatkan bahwa serbuk daun sirih, daun cengkeh dan daun pala memberikan efek yang bisa mematikan jentik. Pengaplikasian serbuk daun sirih, daun cengkeh dan daun pala dilakukan dengan cara di masukkan serbuk kedalam kantong teh (Tea bag) kemudaian dimasukkan kedalam 10 liter air dengan berbagai dosis (1 dan 2 gram). Berdasarkan hasil pengamatan setelah 24 jam pada penelitian ini dengan tiga kali percobaan menunjukan bahwa jumlah rata rata kematian jentik setelah diberikan serbuk daun sirih, daun cengkeh dan daun pala pada dosis 1 gram dan 2 gram yaitu diatas $10 \%$ jentik yang mati.

Percobaan pada serbuk daun sirih dengan dosis 1 gram sudah bisa mematikan jentik dengan rata- 
rata kematian 13,2\% dan pada dosis 2 gram jumlah kematian jentik mencapai $17,2 \%$. Hal yang sama terjadi pada pemberian serbuk daun cengkeh dan daun pala, dengan jumlah kematian jentik pada dosis 1 gram untuk daun cengkeh yaitu 17,2\% dan pada dosis 2 gram jumlah kematian jentik yaitu 22,4\%. Sedangkan pada serbuk daun pala, jumlah kematian jentik pada dosis 1 gram yaitu $12 \%$ dan 2 gram sebanyak $13,2 \%$ kematian jentik. Pada penelitian ini terlihat bahwa setiap menambahkan dosis maka jumlah presentasi kematian pada jentik Aedes aegypti akan meningkat. Penelitian yang dilakukan selama tiga kali percobaan dengan waktu pengamatan selama 24 jam terlihat jumlah jentik yang mati pada setiap percobaan berbeda. Menurut (Supono et al., 2015) adanya perbedaan kematian jentik, salah satu faktor penyebab adalah sifat toksi yang terkandung dalam senyawa kimia tidak stabil sifat toksisitasnya. Selain pengaruh sifat toksi, kematian jentik yang berbeda, juga dapat dipengaruhi faktor dari luar. Menurut (Pradani, 2009) faktor luar yang dapat mempengaruhi kematian jentik diantaranya ketahanan jentik itu sendiri dan kondisi temperatur yang sulit di kontrol.

Pada penelitian ini juga menggunakan kontrol. pada kontrol tidak terdapat kematian jentik dalam tiga kali percobaan. Hal ini menunjukan bahwa air yang digunakan dalam penelitian ini tidak mengandung senyawa kimia yang bisa memberikan efek mematikan pada jentik uji. Jika melihat standar (WHO, 2005) larvasida dinyatakan efektif jika dapat membunuh jentik $\geq 10 \%$ dari total jentik uji. Dari 2 dosis yang dipakai pada penelitian ini, terlihat bahwa dosis 1 dan 2 gram pada semua serbuk yang digunakan, efektif mematikan jentik dalam waktu 24 jam. Dari 3 jenis serbuk yang dipakai pada penelitian ini, terlihat serbuk daun cengkeh lebih efektif dari serbuk daun sirih dan daun pala.

Hasil penelitian (Sakriani et al., 2016) dengan membandingkan perasan daun cengkeh dengan perasan daun pepaya mendapatkan hasil penelitian dimana pada konsentrasi $10 \%$, rata-rata jentik yang mati pada perasan daun cengkeh adalah 4 sedangkan pada perasan daun pepaya hanya 1 . Pada konsentrasi $15 \%$, rata-rata jentik yang mati pada perasan daun cengkeh adalah 10 sedangkan pada perasan daun pepaya hanya 1 . Pada konsentrasi $20 \%$, rata-rata jentik yang mati pada perasan daun cengkeh adalah 10 sedangkan pada perasan daun pepaya hanya 1 . Penelitian ini sejalan dengan penelitian yang dilakukan (Taher, 2015) yang menunjukkan efek larvasida daun cengkeh terhadap jentik Aedes sp dengan konsentrasi infusa daun cengkeh $20 \%$ efektif terhadap kematian jentik nyamuk Ae. aegypti pada 3 jam pertama aplikasi, dan mencapai kematian larva $85 \%$ pada aplikasi selama 15 jam.

Minyak atsiri daun cengkeh (Syzygium aromaticum L.) memiliki efek terhadap mortalitas jentik Aedes aegypti dengan LC50 pada konsentrasi 0,040\% (400 ppm) dan LC99 pada konsentrasi 0,091\% $(910 \mathrm{ppm})$. Efektivitas bahan cengkeh sebagai larvasida diduga dipengaruhi oleh adanya kandungan eugenol sebagai komponen terbesar yang terdapat pada cengkeh. Eugenol yang terdapat pada daun cengkeh, menurut (Haditomo, 2010) dapat mempengaruhi susunan saraf sehingga dapat menyebabkan kematian pada serangga tersebut. Hasil analisis Gas Crhromatography (GC) yang dianalisis secara terpisah menunjukkan kandungan minyak atsiri pada daun cengkeh var. afo adalah sebesar $3.20 \%$ dan eugenol sebesar $90.53 \%$.

Menurut (Medeiros et al., 2013), eugenol pada ekstrak cengkeh merupakan senyawa yang berpotensi sebagai larvasida pada vektor malaria dan DBD. Hal yang sama juga dikemukakan oleh (Almahdy et al., 2006) bahwa berdasarkan nilai LC 50 minyak atsiri dari tanaman cengkeh (LC50 1.76 ppm), minyak kayu putih (LC50 1.99 ppm) memiliki aktivitas yang lebih baik sebagai larvasida dibandingkan abate (LC50 5.33 ppm), sedangkan minyak jambu biji (LC50 5.82 ppm) memiliki aktivitas yang relative sama dengan abate. Penggunaan daun dan bunga cengkeh sebagai larvasida pada jentik Aedes albopictus instar 4 dikemukakan oleh (Bhat \& Kempraj, 2009) bahwa nilai LC50 dan LC95 minyak daun cengkeh adalah 5.3 dan $7.03 \mathrm{mg} / \mathrm{mL}$, sementara minyak cengkeh nilai LC50 dan LC95 17.84 dan $23.99 \mathrm{mg} / \mathrm{mL}$. Dari hasil ini terlihat bahwa toksisitas daun cengkeh lebih tinggi dibanding daun pala, dan daun sirih.

Daun pala dan daun sirih sebenarnya bisa juga dijadikan sebagai larvasida dalam mematikan jentik Aedes aegypti karena, beberapa hasil penelitian lain juga membuktikan ke efektifan dari daun pala dan daun sirih. Hasil penelitian (Mustafa \& Sakriani, 2020) yang menggunakan serbuk daun pala dan daun sirih mendapatkan hasil daun pala lebih efektif dari daun sirih untuk semua dosis. Yaitu, pada daun pala pada dosis 2 gram rata-rata jumlah jentik yang mati yaitu 3 ekor (12\%), dosis 4 gram yaitu 5 ekor (20\%) jentik yang mati, dosis 6 gram yaitu 8 ekor (32\%) jentik yang mati, pada dosis 8 gram yaitu $12(48 \%)$ jentik yang mati dan pada dosis 10 gram yaitu 16 ekor $(64 \%)$ jentik yang mati. Perbedaan penelitian ini dengan penelitian yang dilakukan Mustafa dan Sakriani yaitu pada penelitian ini menggunakan serbuk yang dimasukkan dalam kemasan paper teh bag sedangkan penelitian sebelumnya langsung ditaburkan ke air.

Hasil penelitian lain dari (Mustafa \& Basri, 2019) pada daun pala dalam bentuk perasan menunjukan kematian jentik Aedes Aegypti pada konsentrasi $10 \%$ sebanyak $52 \%$ jentik yang mati untuk konsentrasi $15 \%$ jumlah jentik yang mati sebanyak $68 \%$ dan pada konsentrasi $20 \%$ jumlah jentik yang mati sebanyak $92 \%$. Penelitian ini sejalan dengan penelitian yang dilakukan oleh (Carolina \& Maman, 2016) menunjukkan bahwa aktivitas larvasida A. aegypti daun pala memperlihatkan adanya aktivitas larvasida terhadap Aedes aegypti dengan nilai LC50 sebesar $110.1 \mu \mathrm{g} / \mathrm{mL}$. Hasil penelitian ini diperkuat oleh hasil penelitian (Puspa et al., 2017) pada daun pala dengan 
melakukan uji fitokimia untuk melihat toksisitas minyak atsiri daun pala mendapatkan hasil minyak atsiri pada daun pala memiliki toksisitas terhadapa jentik aedes aegypti sebanyak 3\% tertinggi kosentrasi 300 ppm dapat membunuh $80 \%$ jentik nyamuk. Penggunaan daun pala dalam mematikan jentik Aedes aegypti baik dalam bentuk perasan, serbuk maupun ekstrak terlihat dari beberapa hasil penelitian yang memperlihatkan tingkat kematian jentik uji sangat tinggi pada dosis tertentu.

Pemaparan dari (Rastuti et al., 2013) memaparkan bahwa senyawa yang terkandung pada daun pala diantaranya alkaloida, triterpenoid, tanin, saponin dan flavonoid. Saponin merupakan glikosida dalam tanaman yang sifatnya menyerupai sabun dan dapat larut dalam air. Istilah saponin diturunkan dari bahasa Latin 'SAPO' yang berarti sabun, diambil dari kata SAPONARIA VACCARIA, suatu tanaman yang mengandung saponin digunakan sebagai sabun untuk mencuci. Pengaruh saponin terlihat pada gangguan fisik. Menurut (Novizan, 2002) saponin juga dapat

\section{Daftar Pustaka}

Almahdy, A., Handayani, D., \& Dachriyanus, R. (2006). Uji larvasida dan repelensia beberapa minyak atsiri tanaman famili Myrtaceae terhadap nyamuk Aedes aegypti. Pharmacy, 4, 33-34.

https://sinta.ristekbrin.go.id/affiliations/detail?q $=\mathrm{Uji}+$ larvasida+dan+repelensia + beberapa + min yak+atsiri+tanaman+famili+Myrtaceae+terhad ap+nyamuk+Aedes+aegypti\&search=1\&id=39 $4 \&$ view $=$ documents

Arwadeni, L. (2015). Pengaruh Pemberian Ekstrak Etanol Kulit Buah Dan Daging Buah Pala (Myristica Fragrans Houtt.) Terhadap Mortalitas Larva Aedes Aegypti Instar Iii [Universitas Syiah Kuala]. http://etd.unsyiah.ac.id//index.php?p=show_det ail\&id=12963

Bhat, S. K., \& Kempraj, V. (2009). Biocidal potential of clove oils against Aedes albopictus - A comparative study. African Journal of Biotechnology, 8(24), 6933-6937. https://doi.org/10.4314/ajb.v8i24.68778

Carolina, A., \& Maman, M. (2016). Larvicidal Activity of Essential Oils from the Leaves and Fruits of Nutmeg (Myristica fragrans Houtt) Against Aedes aegypti (Diptera: Culicidae). Turkish Journal of Agriculture - Food Science and Technology, 4(7), 552 https://doi.org/10.24925/turjaf.v4i7.552556.705

Chintihia, T. (2015). Efek Larvasida Ekstrak Daun Cengkeh ( Syzygium aromaticum L . ) terhadap Aedes aegypti Tiara Chintihia The Larvacide Effect of Clove Leaf Extract ( Syzygium aromaticum L .) on Aedes aegypti. J Agromed Unila,

2(4),

$510-515$ masuk melalui organ pernapasan dan menyebabkan membran sel rusak atau proses metabolisme terganggu.

\section{Simpulan dan Saran}

a. Serbuk daun cengkeh dengan dosis 1 dan 2 gram efektif sebagai larvasida dalam 24 jam dengan rata-rata kematian jentik $17,2 \%$ pada dosis 1 gram dan pada dosis 2 gram rata - rata kematian jentik yaitu $22,4 \%$.

b. Serbuk daun pala dengan dosis 1 dan 2 gram efektif sebagai larvasida dalam 24 jam dengan rata-rata kematian jentik $12 \%$ pada dosis 1 gram dan pada dosis 2 gram rata - rata kematian jentik yaitu $13,2 \%$.

c. Serbuk daun pala dengan dosis 1 dan 2 gram efektif sebagai larvasida dalam 24 jam dengan rata-rata kematian jentik $13,2 \%$ pada dosis 1 gram dan pada dosis 2 gram rata - rata kematian jentik yaitu $17,2 \%$.

https://www.google.co.id/url?sa=t\&rct=j\&q=\& esrc $=$ s\&source $=$ web $\& c d=\& c a d=r j a \& u a c t=8 \& v$ ed=2ahUKEwiq7Zng4OPvAhXg6nMBHbtwC 6UQFjABegQIBBAD\&url=https\%3A\%2F\%2 Fjuke.kedokteran.unila.ac.id\%2Findex.php $\% 2 \mathrm{~F}$ agro $\% 2$ Farticle $\% 2$ Fdownload $\% 2$ F $1247 \% 2$ Fpdf \&usg=AOvVaw0HRy8n6V4KqxqQPcZSaYT $\mathrm{N}$

Dinas Kesehatan Kota Ternate, T. (2018). Profil Kesehatan Kota Ternate 2018.

Ditjen P2P, K. kesehatan R. I. (2018). Profil Kesehatan Indonesia 2018 (Vol. 1227, Issue July). https://doi.org/10.1002/qj

Haditomo, I. (2010). Efek Larvasida Ekstrak Daun Cengkeh ( Syzygium aromaticum L . ) Terhadap Aedes aegypti L. Skripsi, 1-39.

Medeiros, E. S., Rodrigues, I. B., Litaiff-abreu, E., Pinto, A. C. S., \& Tadei, W. P. (2013). Larvicidal activity of clove ( Eugenia caryophyllata ) extracts and eugenol against Aedes aegypti and Anopheles darlingi. African Journal of Biotechnology, 12(8), 836-840. https://doi.org/10.4314/ajb.v12i8.

Mustafa, M., \& Basri, A. (2019). Perbandingan Daya Bunuh Daun Pala (Myristica Fragrans) Dan Daun Sirih (Piper Betle L) Sebagai Larvasida Alami Terhadap Larva Aedes Aegypti Instar Iii Di Kota Ternate. Promotif: Jurnal Kesehatan Masyarakat, 9(1), 1-8.

Mustafa, M., \& Sakriani, S. (2020). Efektivitas Serbuk Daun SIRIH (Piper betle L) Dan Daun Pala (Myristica fragrans) Terhadap Kematian Larva Nyamuk Aedes Aegypti. MPPKI (Media Publikasi Promosi Kesehatan Indonesia): The Indonesian Journal of Health Promotion, 3(1), 20-25.Novizan. (2002). Membuat dan 
memanfaatkan pestisida ramah lingkungan. Agro Media Pustaka.

Nugroho, A. D. (2011). Kematian Larva Aedes Aegypti Setelah Pemberian Abate Dibandingkan Dengan Pemberian Serbuk Serai. Jurnal Kesehatan Masyarakat, 7(1), 91-96. https://doi.org/10.1145/2468356.2479613

Pradani, F. Y. (2009). Indeks Pertumbuhan Larva Aedes aegypti L yang Terdedah Dalam Ekstrak Air Kulit Jengkol (Pithecellobium lobatum). Aspirator: Journal of Vector Borne Diseases Studies, 1(2), 81-86. https://doi.org/10.22435/aspirator.v1i2.2934.

Puspa, O. E., Syahbanu, I., \& Wibowo, M. A. (2017). Uji Fitokimia dan Toksisitas Minyak Atsiri Daun Pala ( Myristica fragans Houtt ) dari Pulau Lemukutan. Jkk, 6(2), 1-6.

Rastuti, U., Widyaningsih, S., Kartika, D., \& Ningsih, D. R. (2013). Aktivitas Antibakteri Minyak Atsiri Daun Pala Dari Banyumas Terhadap Staphylococcus aureus DAN Escherichia coli Serta Identifikasi Senyawa Penyusunnya. Molekul Jurnal Ilmiah Kimia, 8(2), 197-203. https://doi.org/10.20884/1.jm.2013.8.2.142

Sakriani, Hidayat, N. I., \& Dianita, N. (2016). Pepaya Terhadap Mortalitas Larva Aedes Aegepty Di. 9(2010), $22-26$ http://ejournal.poltekkesternate.ac.id/ojs/index. php/juke/article/view/101/58
Supono, Sugiyarto, Susilowati, A., Purwantisari, S., \& Kurniawati, F. N. (2015). Biokontrol larva nyamuk Aedes aegypti menggunakan limbah biji karika (Vasconcellea pubescens). PROS SEM NAS MASY BIODIV INDON, 1(5), 1127-1131. https://doi.org/10.13057/psnmbi/m010427

Sutanto, I. (2015). Buku ajar parasitologi kedokteran (Ke empat ed.) (Ke Empat). Jakarta: Badan Penerbit FK UI.

Taher, D. M. (2015). Potensi cengkeh (Syzygium aromaticum) varietas Afo sebagai larvasida alami nyamuk Anopheles subpictus dan Aedes aegypti. 1(September), 1478-1482. https://doi.org/10.13057/psnmbi/m010637

Utomo, M., Amaliah, S., \& Suryati, F. A. (2010). Daya Bunuh Bahan Nabati Serbuk Biji Papaya Terhadap Kematian Larva Aedes aegypti Isolat Laboratorium B2P2VRP Salatiga. Prosiding Seminar Nasional Unimus, 152-158.

WHO. (2005). Guidelines for laboratory and field testing of mosquito larvicides. World Health Organization, 1-41. http://whqlibdoc.who.int/ hq/2005/WHO_CDS_WHOPES_GCDPP_200 5.13.pdf?ua $=1$

WHO. (2017). Severe Dengue Research. https://www.who.int/news-room/factsheets/detail/dengue-and-severe-dengue 